\title{
KARASTERISTIK CURAH HUJAN DAN ALIRAN DAS LARONA KABUPATEN LUWU TIMUR SULAWESI SELATAN
}

\author{
Djazim Syaifullah ${ }^{*}$
}

\begin{abstract}
Intisari
Karasteristik curah hujan dan aliran DAS Larona telah dilakukan dengan menggunakan data curah hujan dan aliran (inflow). Data curah hujan 7 buah stasiun data bulanan dan harian 10 sampai 29 tahun dan 8 buah stasiun penakar otomatis untuk mendapatkan data jam-jaman. Nilai inflow biasanya dihitung berdasarkan data outflow. Hasilnya menunjukkan bahwa daerah di sekitar Mahalona, bagian tenggara Matano dan bagian Barat Laut Towuti mempunyai konsentrasi curah hujan yang paling besar. DAS ini masuk musim kering pada bulan Agustus dan September, sementara bulan bulan yang lain termasuk bulan basah. Curah Hujan bulanan maksimum terjadi pada bulan April dengan nilai sekitar $360 \mathrm{~mm}$, sedangkan curah hujan bulanan minimum terjadi pada bulan September sekitar $105 \mathrm{~mm}$. DAS Larona didominasi oleh hujan ringan (kurang dari $5 \mathrm{~mm}$ dalam satu harinya) dengan durasi hujan dominan kurang dari 1 jam (rata-rata sekitar $47 \%$ dari total kejadian hujan). Dari nilai koefisien aliran yang berkisar 0.6 menunjukkan bahwa DAS Larona masih berada pada kondisi moderate dalam hal sebagai reservoir air
\end{abstract}

\begin{abstract}
Precipitation and flow charasteristics of the Larona watershed was conducted by use of the rainfall and inflow data. There are monthly and daily rainfall data 10 until 29 year long for 7 8 automatic rainfall stations. The value of inflow was calculated based on outflow. The results show that the region around Mahalona, the southeastern of Matano and part of Northwest of Towuti have the most concentration of rainfall. This Catchment came into rainy season on August until September, while other month in the rainy season. Maximum monthly rainfall occurs in april with the value of around $360 \mathrm{~mm}$, while the minimum monthly rainfall happened in september around $105 \mathrm{~mm}$. The Llarona catchment was dominated by light rain (less than $5 \mathrm{~mm} /$ day) with the duration of rainfall less than $1 \mathrm{~mm} /$ hour. From the value of the stream coefficients shows that Larona Catchment are still at moderate condition in terms as water reservoirs
\end{abstract}

Kata kunci : Karasteristik curah hujan, aliran, DAS Larona

\section{PENDAHULUAN}

Daerah Aliran Sungai (DAS) adalah wilayah yang terletak di atas suatu titik pada suatu sungai yang oleh batas topografi mengalirkan air yang jatuh di atasnya kedalam sungai yang sama dan melalui titik yang sama pada sungai tersebut. Salah satu unsur suaca yang sangat penting dan mempunyai dampak yang signifikan terhadap fluktuasi penyediaan sumber daya air adalah hujan. Hujan merupakan masukan utama dalam suatu sistem hidrologi Daerah Aliran Sungai melalui daerah tangkapan hujan (cacthment area) yang mengelilingi alur aliran sungai tersebut. Oleh karena itu dalam pengelolaan sumber daya air maka perhitungan masukan utama air melalui hujan merupakan hal yang penting, demikian juga pemahaman tentang karasteristik hujan baik sifat spasial (sebaran) maupun temporalnya (durasi, intensitas). Parameter hidrologi lain yang perlu mendapat perhatian dalam perencanaan pengelolaan sumberdaya air di dalam DAS adalah aliran. Dengan mempelajari karasteristik aliran dan curah hujan maka dapat membantu dalam pengelolaan DAS.

DAS Larona (luas tangkapan hujan sekitar 2440 km2) terletak di Kecamatan Malili Kabupaten Luwu Timur Sulawesi Selatan yang terdiri dari mempunyai 3 (tiga) danau yang cukup besar yang membentuk kaskade yaitu Danau Matano, Danau Mahalona dan Danau Towuti. Di daerah ini terdapat perusahaan penambangan nikel terbesar di Indonesia, PT INCO Indonesia. Untuk keperluan energi listriknya perusahaan tersebut memanfaatkan aliran sungai Larona yang dibendung diujung Danau Towuti pada sungai Laharona.

Tujuan dari penelitian ini adalah melakukan analisis karasteristik curah hujan DAS Larona

\footnotetext{
${ }^{*}$ Peneliti Madya - UPT Hujan Buatan, BPPT, Thamrin No. 8 Jakarta, email djazimsy@yahoo.com
} 
meliputi sebaran curah hujan (analisis spasial), analisis historis curah hujan, analisis time series curah hujan bulanan, analisis hari hujan, analisis durasi dan intensitas curah hujan serta analisis karasteristik aliran.

\subsection{Daerah Penelitian}

Daerah penelitian yang digunakan adalah

DAS Larona seperti terlihat pada Gambar 1. Di
DAS Larona terdapat tiga danau yaitu Towuti, Mahalona dan Matano yang terhubung secara kaskade. Kondisi topografi wilayah ini dicirikan dengan daerah perbukitan, relatif landai di sebelah Barat dan cukup curam pada sisi bagian utara dan timurnya. Sebagian besar permukaan lahannya masih tertutup oleh vegetasi berupa hutan tropis.

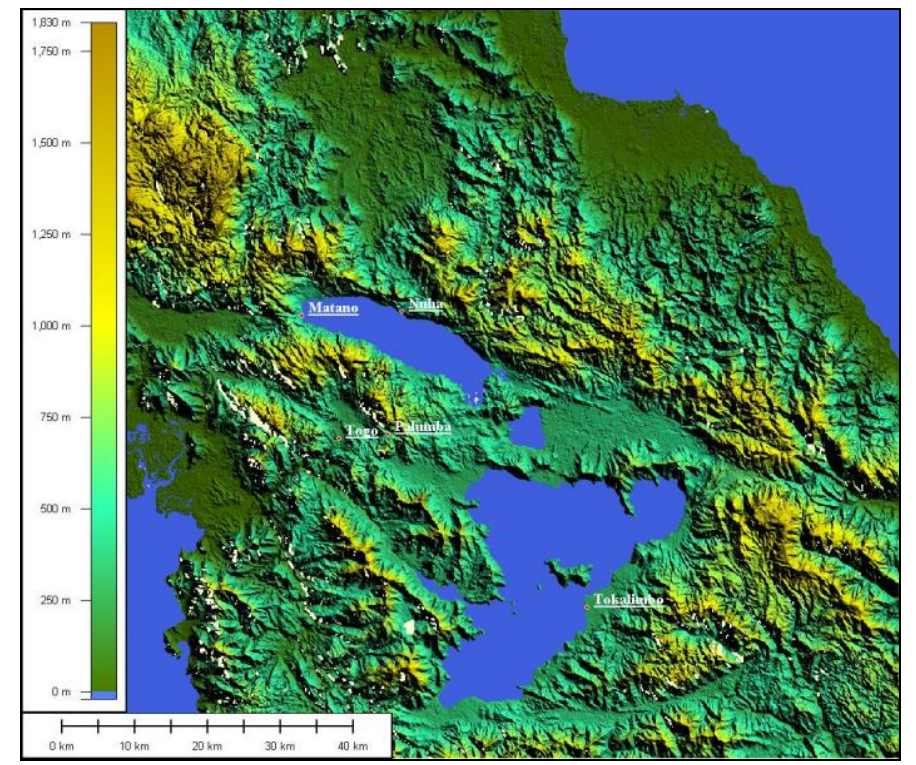

Gambar 1. Daerah kerja dari kegiatan ini yang mencakup DAS Larona yang meliputi Danau Towuti, Mahalona dan Matano di Kabupaten Malili Sulawesi Tengah.

\section{DATA DAN METODE}

\subsection{Data Curah Hujan}

Data curah hujan yang digunakan dalam penelitian ini meliputi seluruh DAS Larona, dengan pertimbangan kelengkapan data dan sebaran posisi stasiun dilakukan stratifikasi stasiun yang hasilnya terlihat pada Tabel 1. Dari hasil statrifikasi diperoleh 15 buah data yang terdiri dari 7 (tujuh) buah data bulanan dan harian dengan panjang data 10 tahun sampai 29 tahun, serta 8 (delapan) buah data jam-jaman dengan panjang data sekitar 3 bulan.

Data bulanan digunakan untuk analisis curah hujan historis bulanan, analisis curah hujan bulanan time series, analisis spasial curah hujan tahunan. Data curah hujan harian digunakan untuk analisis hari hujan, sedangkan data dengan interval jam-jaman digunakan untuk analisis durasi hujan dan analisis intensitas curah hujan.

Tabel 1. Daftar Stasiun Curah Hujan yang digunakan, posisi lintang bujur dan keberadaan data (sumber : $P T$ INCO)

\begin{tabular}{|c|c|c|c|c|c||}
\hline No. & Nama Stasiun & Bujur & Lintang & Data & Pjg data) \\
\hline \hline 1 & Wawondula & $121.310 \mathrm{BT}$ & $2.630 \mathrm{LS}$ & Harian/Bulanan & 27 th $(1979 \sim 2005)$ \\
\hline 2 & Plant Site & $121.381 \mathrm{BT}$ & $2.567 \mathrm{LS}$ & Harian/Bulanan & 29 th $(1977 \sim 2005)$ \\
\hline 3 & Tokalimbo & $121.568 \mathrm{BT}$ & $2.815 \mathrm{LS}$ & Harian/Bulanan & 10 th $(1996 \sim 2005)$ \\
\hline 4 & Timampu & $121.428 \mathrm{BT}$ & $2.657 \mathrm{LS}$ & Harian/Bulanan & 20 th $(1986 \sim 2005)$ \\
\hline 5 & Matano & $121.216 \mathrm{BT}$ & $2.456 \mathrm{LS}$ & Harian/Bulanan & 10 th (1996 2005) \\
\hline 6 & Nuha & $121.340 \mathrm{BT}$ & $2.447 \mathrm{LS}$ & Harian/Bulanan & 10 th (1996 2005) \\
\hline 7 & Damsite & $121.300 \mathrm{BT}$ & $2.710 \mathrm{LS}$ & Harian/Bulanan & 18 th (1988 2005) \\
\hline 8 & Lioka & $121.326 \mathrm{BT}$ & $2.634 \mathrm{LS}$ & Jam-jaman & 1 bln (May 2005) \\
\hline 9 & Karebe & $121.150 \mathrm{BT}$ & $2.676 \mathrm{LS}$ & Jam-jaman & 1.5 bln (Apr May 05) \\
\hline 10 & Timampu & $121.428 \mathrm{BT}$ & $2.657 \mathrm{LS}$ & Jam-jaman & 3 bln (Mar May 2005) \\
\hline 11 & Tokalimbo & $121.568 \mathrm{BT}$ & $2.815 \mathrm{LS}$ & Jam-jaman & 3 bln (Mar May 2005) \\
\hline 12 & Matano & $121.216 \mathrm{BT}$ & $2.456 \mathrm{LS}$ & Jam-jaman & 3 bln (Mar May 2005) \\
\hline 13 & Nuha & $121.340 \mathrm{BT}$ & $2.447 \mathrm{LS}$ & Jam-jaman & 3 bln (Mar May 2005) \\
\hline 14 & Palumba & $121.322 \mathrm{BT}$ & $2.596 \mathrm{LS}$ & Jam-jaman & 3 bln (Mar May 2005) \\
\hline 15 & Togo & $121.262 \mathrm{BT}$ & $2.606 \mathrm{LS}$ & Jam-jaman & 3 bln (Mar May 2005) \\
\hline \hline
\end{tabular}




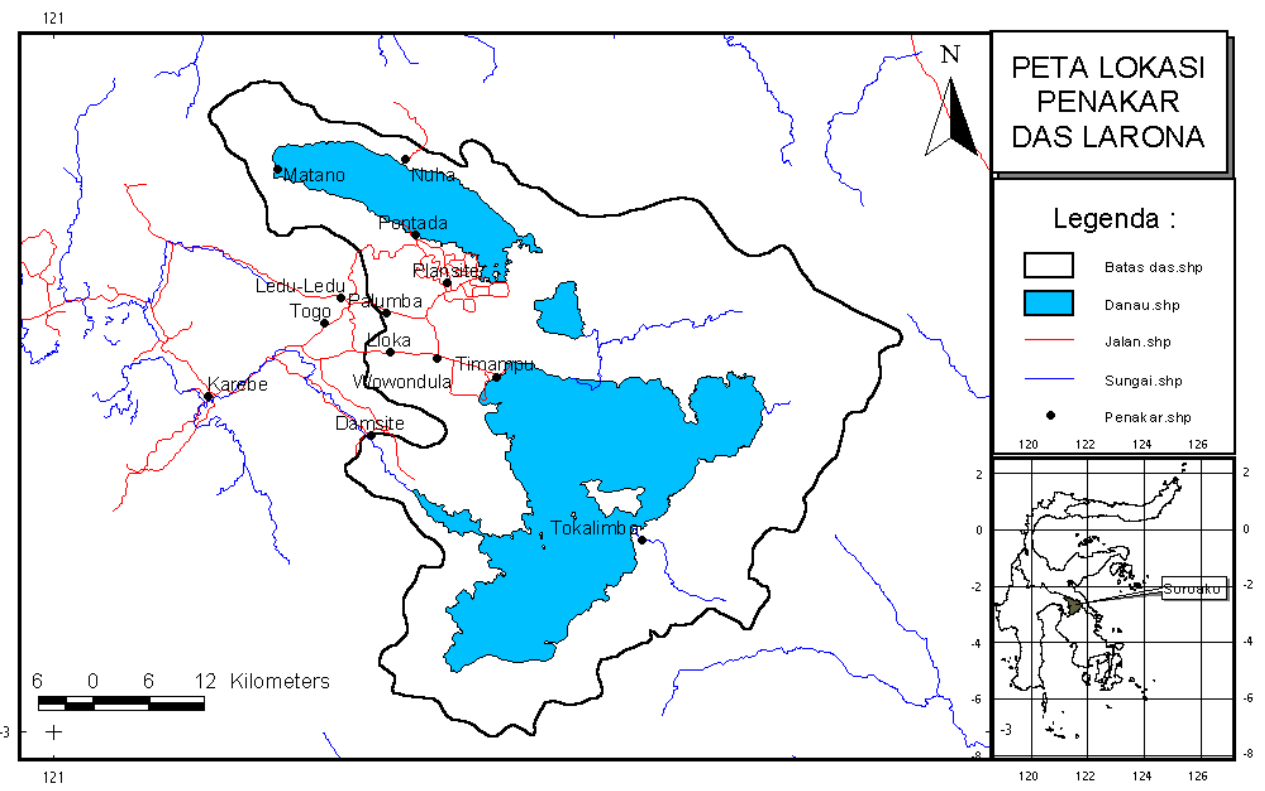

Gambar 2. Distribusi posisi stasiun penakar curah hujan harian seperti dalam Tabel 1.

\subsection{Data Aliran}

Data aliran berupa outflow yang terukur di Hydro Power PT INCO dengan menggunakan Ultrasonic Flow Measuring Devices. Komponen inflow dari DAS Larona tidak diukur secara langsung karena secara teknis di lapangan sulit dilakukan.

Nilai inflow biasanya dihitung berdasarkan data outflow (terdiri dari Canal flow dan Spillway flow) serta Tinggi Muka Air (TMA) yang diukur di Towuti.

Persamaan yang digunakan adalah :

InFlow $=$ NetStorage + CanalFlow + SpillwayFlow

Canal flow dihitung berdasarkan formula yang disarankan oleh PRP Feasibility Study Report, Juli 1995 (anonymous, 1995 dalam Tauhid, 2000) sebagai berikut :

CanalFlow $=$ PenstockFlow +1

angka 1 merupakan faktor koreksi karena adanya Canal leakage sebesar $1 \mathrm{~m}^{3} /$ detik. Spillway flow dihitung langsung berdasarkan tabel konversi, sementara storage dihitung dengan persamaan lengkung debit (rating curve) yang menyatakan hubungan antara storage dengan TMA.

$S=5.03750 \cdot L^{2}-2630.81 \cdot L+328312$

dimana : $\mathrm{S}=$ storage Towuti (MCM, juta meter kubik), $L=$ TMA Towuti (m), yang selanjutnya akan diperoleh,

NetStorage $=$ TodayStorage - YesterdayStorage

Hubungan antara TMA dengan besarnya storage dan luas permukaan air untuk Danau Towuti ditunjukkan pada Tabel 3 (Tauhid, 2000).
Tabel 2. Hubungan antara elevasi, luas permukaan air dan storage Danau Towuti

\begin{tabular}{|c|c|c|}
\hline $\begin{array}{c}\text { Elevasi } \\
(\mathrm{m})\end{array}$ & $\begin{array}{c}\text { Luas perm air } \\
\left(\mathrm{km}^{2}\right)\end{array}$ & $\begin{array}{c}\text { Storage } \\
\left(\mathrm{m}^{3} .106\right)\end{array}$ \\
\hline \hline 316.0 & 553 & 0 \\
\hline 317.0 & 563 & 558 \\
\hline 318.0 & 573 & 1126 \\
\hline 318.3 & 576 & 1298 \\
\hline 318.6 & 579 & 1472 \\
\hline 319.0 & 583 & 1704 \\
\hline 319.3 & 586 & 1879 \\
\hline 319.6 & 589 & 2056 \\
\hline 320.2 & 595 & 2411 \\
\hline 322.0 & 617 & 3502 \\
\hline 323.0 & 635 & 4128 \\
\hline 324.0 & 660 & 4775 \\
\hline 325.0 & 667 & 5176 \\
\hline 326.0 & 727 & 6159 \\
\hline
\end{tabular}

\subsection{Metode}

Metode yang dilakukan adalah melakukan analisis spasial curah hujan DAS Larona, melakukan analisis curah hujan bulanan historis, curah hujan bulanan time series, serta analisis hari hujan. Untuk mengetahui karasteristik curah hujan dilakukan analisis durasi hujan dan intensitas hujan.

Analisis spasial dilakukan dengan membuat peta isohyet dengan menggunakan perakngkat ArcView dan Surfer, sementara analisis time series dan analisis historis diolah dengan menggunakan Microsoft Excel.

\subsection{Morfometri DAS Larona}

DAS Larona terletak di Kabupaten Luwu Timur Sulawesi Selatan, mempunyai luas sekitar 
$2440 \mathrm{~km}^{2}$ merupakan daerah aliran sungai yang unik, karena mempunyai 3 (tiga) danau yang cukup besar yang membentuk kaskade yaitu Danau Matano, Danau Mahalona dan Danau Towuti. Kondisi topografi kebanyakan berbukit terjal sebagai bagian dari pegunungan Verbeek, dengan elevasi berkisar di antara $100-1700$ meter di atas permukaan laut (dpl). Sebelah Timur laut dibatasi oleh bukit dengan ketinggian sekitar 1300 meter dpl dan sebelah Barat Laut Matano dibatasi oleh perbukitan dengan ketinggian sekitar 1700 meter dpl.

Daerah Tangkapan Hujan bagi DAS ini hanya berupa daerah sempit yang mengelilingi ketiga danau tersebut. Dengan permukaan air danau yang cukup luas seperti ini maka pembentukan awan dan hujan memiliki karakteristik tersendiri, baik lokasi awal pembentukan awan, maupun waktu terjadinya hujan.

Luas Danau Matano sekitar $157 \mathrm{~km}^{2}$ dengan ketinggian muka air sekitar 394 meter dpl, Luas Danau Mahalona sekitar $21.7 \mathrm{~km}^{2}$ dengan ketinggian muka air sekitar 324 meter dpl, sedangkan luas Danau Tomuti sekitar $540 \mathrm{~km}^{2}$ dengan ketinggian muka air 319 meter dpl.

Sungai utama di DAS ini adalah sungai Laharona yang mengalir dari outlet Danau Towuti yang mengalir menuju teluk Bone, Malili. Pada sungai ini dibangun PLTA Batubesi dan Balambano dengan membendung sungai
Laharona untuk menghasilkan listrik bagi keperluan pertambangan Nikel PT. INCO. Dalam rencananya juga akan dibangun pembangkit lagi di Karebe pada arah hilir di sungai yang sama. Tabel 3 berikut menampilkan Luas tangkapan hujan dan luas permukaan air untuk ketiga waduk di DAS Larona.

Tabel 3. Luas tangkapan Hujan dan permukaan air DAS Larona $\left(\mathrm{km}^{2}\right.$, Sumber : PT INCO)

\begin{tabular}{||c|c|c||}
\hline $\begin{array}{c}\text { Nama } \\
\text { Danau }\end{array}$ & Tangkapan hujan & Permukaan air \\
\hline \hline Matano & 482.6 & 157 \\
\hline Mahalona & 260.9 & 21.7 \\
\hline Towuti & 1700.4 & 540 \\
\hline Total & $\mathbf{2 4 4 3 . 7}$ & $\mathbf{7 1 8 . 7}$ \\
\hline
\end{tabular}

\section{HASIL}

\subsection{Karasteristik Curah Hujan DAS Larona}

Untuk melihat sebaran / distribusi curah hujan tahunan DAS Larona dibuat peta sebaran curah hujan (isoyet). Peta isoyet ini menggunakan data curah hujan yang diambil dari 7 (tujuh) buah stasiun curah hujan bulanan dengan panjang data 10 sampai 29 tahun seperti dalam Tabel 1. Ketujuh stasiun tersebut berada dalam DAS Larona. Sebaran curah hujan tahunan dapat diperlihatkan dalam Gambar 3.

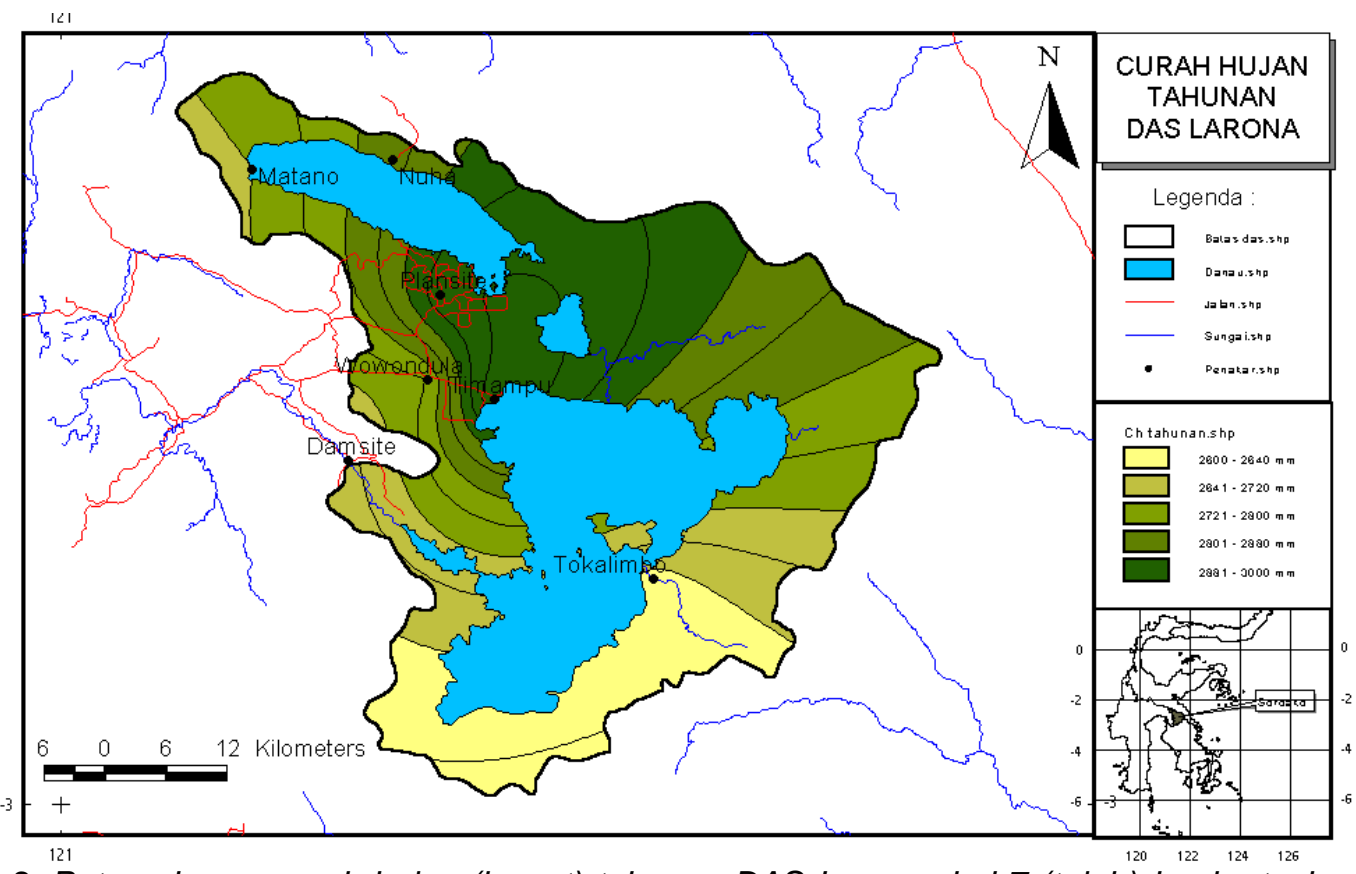

Gambar 3. Peta sebaran curah hujan (isoyet) tahunan DAS Larona dari 7 (tujuh) buah stasiun penakan dengan panjang data 10 29 tahun (UPT Hujan Buatan, 2005).

Dari Gambar 3 terlihat bahwa sebaran curah hujan tahunan mempunyai nilai yang tinggi di sekitar daerah Danau Mahalona yang mencapai $3000 \mathrm{~mm} / \mathrm{tahun}$, sedangkan curah hujan tahunan yang paling rendah berada di bagian selatan dari
Danau Towuti dengan nilai sekitar $2600 \mathrm{~mm} /$ tahun. Daerah-daerah di sekitar Mahalona, bagian tenggara Matano dan bagian Barat Laut Towuti mempunyai konsentrasi curah hujan ayang paling besar. 
Perbedaan antara curah hujan tahunan maksimum dengan curah hujan tahunan minimum tidak terlalu besar yaitu $400 \mathrm{~mm}$, yang mengindikasikan bahwa curah hujan tahunan DAS Larona relatif seragam.

\subsection{Profil Curah Hujan Historis}

Profil curah hujan bulanan historis diambil dari data curah hujan bulanan dari 7 stasiun curah hujan yang ada dalam Tabel 1. yang mempunyai panjang data bulanan selama 10 sampai 29 tahun. Perhitungan curah hujan wilayah ini menggunakan metode Rerata Aritmatik untuk ke-7 stasiun tersebut. Grafik curah hujan wilayah bulanan historis dapat dilihat pada Gambar 4.

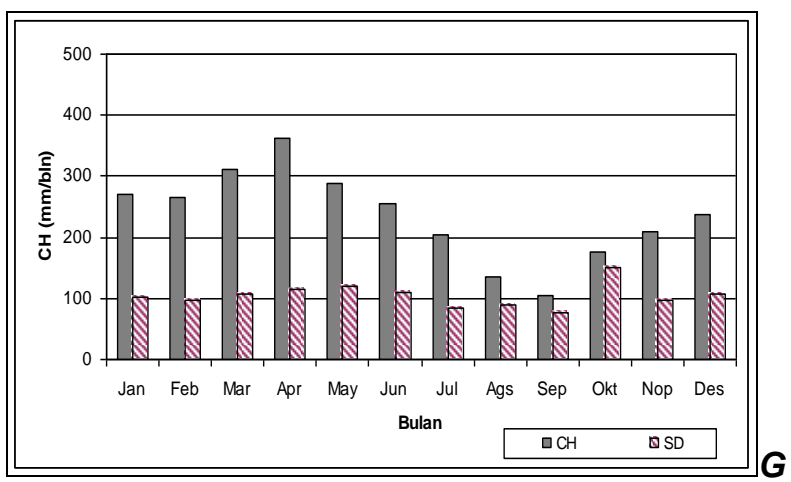

Gambar 4. Profil curah hujan bulanan historis wilayah DAS Larona dan nilai Standar deviasinya (diambil dari 7 stasiun data bulanan dengan panjang data 10 29 tahun).

Pola curah hujan historis DAS Larona termasuk dalam pola bimodal (memiliki dua puncak) yang merupakan ciri khas daerah dekat ekuator. Dari definisi bulan basah yaitu bulan yang curah hujannya di atas $150 \mathrm{~mm}$ maka dari sifat curah hujan musiman DAS Larona masuk musim kering pada bulan Agustus dan September, sementara bulan bulan yang lain termasuk bulan basah.

Curah Hujan bulanan maksimum terjadi pada bulan April dengan nilai sekitar $360 \mathrm{~mm}$, sedangkan curah hujan bulanan minimum terjadi pada bulan September sekitar $105 \mathrm{~mm}$. Ternyata pada bulan Oktober variasi curah hujannya sangat besar dibandingkan pada bulan-bulan lain seperti terlihat dari nilai standar deviasinya.

\subsection{Curah Hujan Bulanan Time Series}

Secara grafik curah hujan bulanan time series dapat dilihat pada Gambar L1 lampiran, yang diwakili stasiun Plansite, Wawondula dan
Timampu dengan panjang pengamatan 20 sampai 29 tahun. Dari data time series tersebut dapat dilihat bahwa curah hujan untuk ketiga stasiun berfluktuasi mengikuti pola diurnal. Pada bulanbulan basah dari ketiga stasiun tersebut pernah mengalami curah hujan maksimum mencapai 600 $\mathrm{mm} /$ bulan di beberapa tahun.

\subsection{Analisis Durasi Curah Hujan}

Karasteristik hujan dapat dilihat dengan data hujan interval satu jam dari suatu DAS. Dengan keterbatasan data dan pertimbangan distribusi stasiun yang mewakili kondisi DAS maka dipilih tiga stasiun yaitu : Stasiun Timampu, Tokalimbo dan Stasiun Matano. Panjang data pengamatan jam-jaman adalah tiga bulan (Maret sampai Mei 2005) seperti terlihat pada Tabel 1.

Dilihat dari Gambar 2, maka posisi ketiga stasiun relatif lebih mewakili DAS, Stasiun Timampu dan Tokalimbo mewakili Danau Towuti sedangkan Stasiun Matano mewakili Danau Matano. Untuk melihat lamanya kejadian hujan (durasi) dalam satuan jam pada ketiga stasiun tersebut dibuat grafik jumlah kejadian berdasarkan lamanya kejadian hujan (dalam jam) yang hasilnya dapat dilihat pada Gambar 5 .

Jumlah kejadian hujan selama periode pengamatan tiga bulan Stasiun Timampu sebanyak 123 kejadian hujan, Stasiun Tokalimbo sebanyak 50 kejadian hujan sedangkan Stasiun Matano sebanyak 117 kejadian hujan. Panjang kejadian hujan maksimum selama periode pengamatan untuk Stasiun Timampu adalah 8 jam yang terjadi pada tanggal 12 Mei jam 02:00 sampai 09:00 WITA sebesar $48 \mathrm{~mm}$ (intensitas 6 $\mathrm{mm} / \mathrm{jam}$ ), untuk Stasiun Tokalimbo adalah 16 jam yang terjadi pada tanggal 26 Maret jam 06:00 sampai 21:00 WITA sebesar $311 \mathrm{~mm}$ (intensitas $19.4 \mathrm{~mm} / \mathrm{jam}$ ), sedangkan Stasiun Matano adalah 10 jam yang terjadi pada tanggal 9 April jam 14:00 sampai 23:00 WITA sebesar $70 \mathrm{~mm}$ (intensitas 7 $\mathrm{mm} / \mathrm{jam})$.

Dari Gambar 5 secara umum terlihat bahwa ketiga Stasiun mempunyai jumlah kejadian hujan yang dominan kurang dari 1 jam (rata-rata sekitar $47 \%$ dari total kejadian hujan). Secara umum juga terlihat durasi hujan untuk ketiga stasiun pengamatan mencapai enam jam. Untuk melihat sebaran intensitas curah hujan dilakukan analisis intensitas curah hujan. 


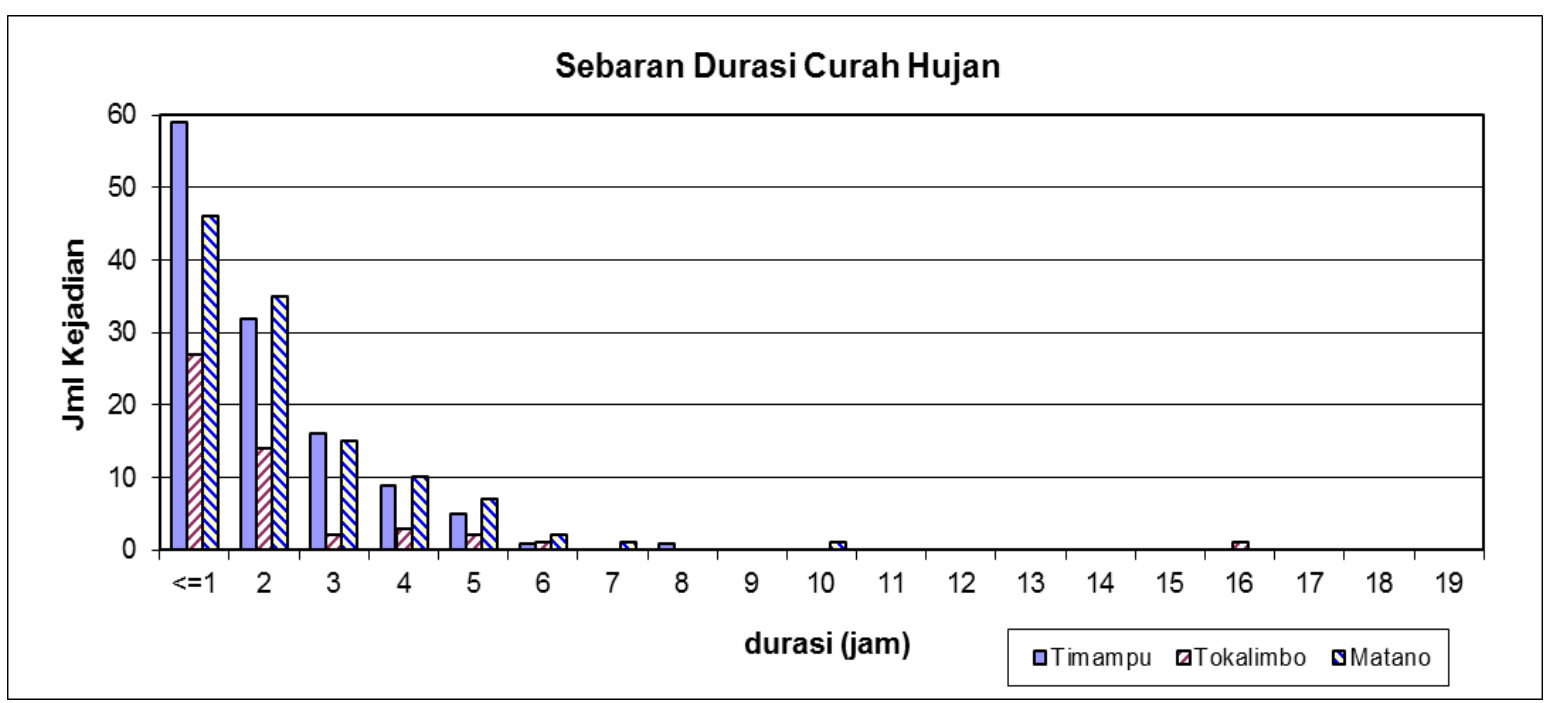

Gambar 5. Sebaran durasi (lama kejadian hujan) untuk ketiga stasiun pengamatan Timampu, Tokalimbo dan Matano pada periode Maret Mei 2005 (diolah dari sumber : PT INCO).

\subsection{Analisis Intensitas Curah Hujan}

Analisis intensitas curah hujan dilakukan untuk seluruh stasiun curah hujan di DAS Larona. Gambar L2. pada lampiran, menunjukkan contoh intensitas curah hujan untuk ketiga stasiun pengamatan Timampu, Tokalimbo dan Nuha selama bulan Maret sampai May tahun 2005. Dari ketiga stasiun terlihat intensitas yang bervariasi dan pernah mencapai intensitas di atas 30 $\mathrm{mm} / \mathrm{jam}$. Tetapi secara umum intensitas curah hujan berada di bawah $100 \mathrm{~mm} / \mathrm{jam}$.

Gambar 6 adalah sebaran jumlah kejadian intensitas curah hujan (mm/jam) untuk ketiga stasiun pengamatan Timampu, Tokalimbo dan Matano pada periode Maret $\sim$ Mei 2005.

Dari Gambar 6 secara umum terlihat bahwa ketiga stasiun mempunyai jumlah intensitas hujan yang dominan kurang dari $1 \mathrm{~mm} / \mathrm{jam}$ (rata-rata sekitar $36 \%$ dari total kejadian hujan).

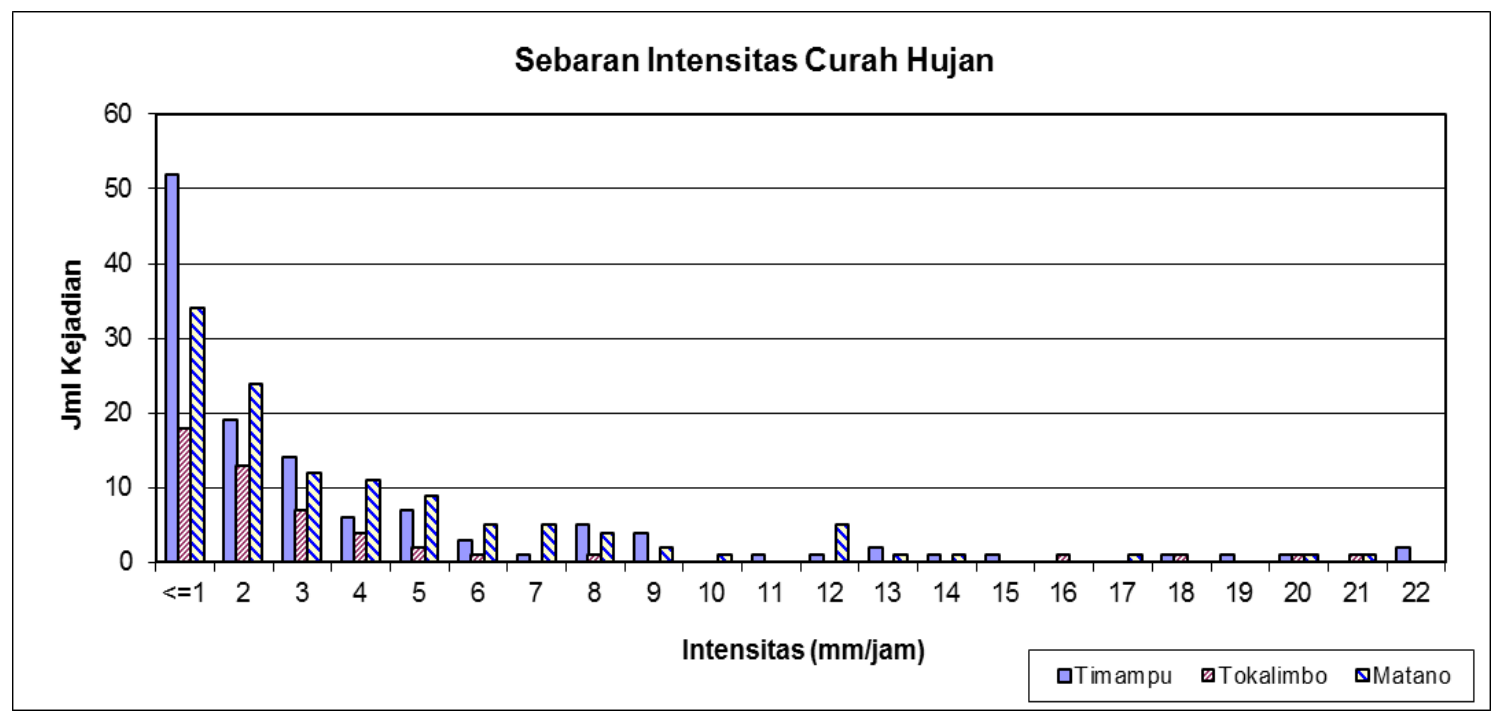

Gambar 6. Sebaran Intensitas curah hujan untuk ketiga stasiun pengamatan Timampu, Tokalimbo dan Matano pada periode Maret Mei 2005 (diolah dari sumber : PT INCO).

\subsection{Analisis Hari Hujan}

Analisis Hari hujan dilakukan untuk melihat jumlah hari hujan historisnya untuk setiap bulannya. Dalam keperluan Teknologi Modifikasi Cuaca (TMC), informasi ini sangat penting untuk melihat berapa jumlah hari hujan pada bulan tertentu sehingga dapat digunakan untuk menentukan strategi dalam Penerapan TMC misalnya berapa jumlah bahan semai yang diperlukan dan berapa jumlah jam terbang (sorti) yang diperlukan. Hasil analisis ini berguna sebagai masukan untuk menentukan Rencana Anggaran dan Biaya (RAB) yang ditawarkan ke user. Stasiun yang dipakai dalam analisis ini adalah 3 (tiga) stasiun yaitu Stasiun Timampu, Tokalimbo dan Matano yang mempunyai panjang data Harian 10 sampai 18 tahun. Contoh grafik Hari hujan serta standar deviasi untuk stasiun Tokalimbo dapat dilihat pada Gambar 7. 


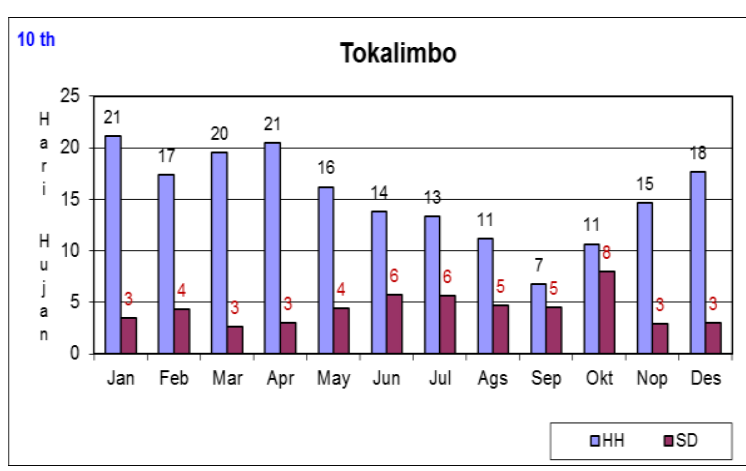

Gambar 7. Jumlah Hari Hujan untuk Stasiun Tokalimbo dengan panjang data 10 tahun.

Secara keseluruhan jumlah total hari hujan dan hari hujan historis untuk ke-3 stasiun yang dianalisis dapat dilihat pada Tabel 4. Dari hasil analisis intensitas curah hujan yang menunjukkan dominasi intensitas ringan kurang dari atau sama dengan $1 \mathrm{~mm} / \mathrm{jam}$ dengan durasi sekitar 1 sampai 2 jam, hujan dengan intensitas seperti ini kurang signifikan dalam pertambahan aliran yang masuk ke tiga waduk. Karena DAS Larona didominasi oleh hujan ringan, maka dibuat tabel Hari hujan dengan curah hujan $>5 \mathrm{~mm}$ dalam satu harinya. Untuk total hari hujan, DAS Larona mempunyai jumlah hari hujan rerata sekitar 20 hari pada bulan basah dan 12 hari pada bulan kering, sedangkan hari hujan dengan stratifikasi curah hujan di atas $5 \mathrm{~mm}$, DAS Larona mempunyai jumlah hari hujan rerata sekitar 11 hari pada bulan basah dan 6 hari pada bulan kering.

Stasiun Timampu 69\% dari total hari hujan adalah hari hujan dengan jumlah hujannya kurang dari $5 \mathrm{~mm}$ dalam satu harinya, sedangkan untuk Tokalimbo dan Matano masing-masing adalah $21 \%$ dan $49 \%$.

Tabel 4. Jumlah total Hari Hujan dari 3 stasiun di DAS Larona

\begin{tabular}{|c|c|c|c|c|c|c|c|c|c|c|c|c|c|c|c|}
\hline \multirow{2}{*}{ No } & \multirow{2}{*}{$\begin{array}{c}\text { Nama } \\
\text { Stasiun }\end{array}$} & \multirow{2}{*}{$\begin{array}{c}\text { Pjg } \\
\text { Data } \\
\end{array}$} & \multicolumn{13}{|c|}{ Jumlah Total Hari Hujan } \\
\hline & & & & Jan & Feb & Mar & Apr & May & Jun & Jul & Ags & Sep & Okt & Nop & Des \\
\hline \multirow{2}{*}{1} & \multirow{2}{*}{ Timampu } & \multirow{2}{*}{18 thn } & AVG & 19 & 19 & 19 & 23 & 21 & 21 & 19 & 13 & 9 & 10 & 14 & 16 \\
\hline & & & SD & 6 & 5 & 7 & 5 & 5 & 6 & 6 & 7 & 5 & 7 & 4 & 5 \\
\hline \multirow{2}{*}{2} & \multirow{2}{*}{ Tokalimbo } & \multirow{2}{*}{10 thn } & AVG & 21 & 17 & 20 & 21 & 16 & 14 & 13 & 11 & 7 & 11 & 15 & 18 \\
\hline & & & SD & 3 & 4 & 3 & 3 & 4 & 6 & 6 & 5 & 5 & 8 & 3 & 3 \\
\hline \multirow{3}{*}{3} & \multirow{2}{*}{ Matano } & \multirow{2}{*}{10 thn } & $A V G$ & 24 & 24 & 26 & 26 & 24 & 25 & 22 & 16 & 14 & 14 & 18 & 23 \\
\hline & & & $S D$ & 6 & 4 & 3 & 4 & 6 & 4 & 5 & 8 & 7 & 10 & 5 & 3 \\
\hline & & & \multicolumn{13}{|c|}{ Jumlah Hari Hujan dengan Curah Hujan $>5 \mathrm{~mm}$} \\
\hline \multirow{2}{*}{1} & \multirow{2}{*}{ Timampu } & \multirow{2}{*}{18 thn } & AVG & 7 & 7 & 6 & 6 & 8 & 8 & 7 & 5 & 3 & 3 & 5 & 6 \\
\hline & & & $S D$ & 4 & 3 & 4 & 2 & 5 & 4 & 3 & 3 & 3 & 3 & 2 & 3 \\
\hline \multirow{2}{*}{2} & \multirow{2}{*}{ Tokalimbo } & \multirow{2}{*}{10 thn } & $A V G$ & 17 & 15 & 16 & 17 & 13 & 11 & 10 & 7 & 6 & 8 & 12 & 14 \\
\hline & & & $S D$ & 4 & 4 & 3 & 4 & 4 & 5 & 5 & 3 & 4 & 6 & 3 & 4 \\
\hline \multirow{2}{*}{3} & \multirow{2}{*}{ Matano } & \multirow{2}{*}{10 thn } & $A V G$ & 13 & 16 & 13 & 15 & 12 & 14 & 10 & 7 & 5 & 7 & 10 & 10 \\
\hline & & & $S D$ & 5 & 4 & 3 & 5 & 4 & 3 & 4 & 5 & 3 & 6 & 4 & 3 \\
\hline
\end{tabular}

\subsection{Karasteristik Aliran Sungai}

Sungai utama yang mengaliri DAS Larona adalah Sungai Laharona dengan panjang aliran sungai mencapai $45 \mathrm{~km}$ bermuala di Teluk Bone, Malili. Karena Danau Towuti juga merupakan danau alami, maka tinggi muka air (TMA) maksimum danau ditentukan oleh aktifitas pertanian penduduk seputaran danau.

Fluktuasi TMA ini berbeda dengan fluktuasi inflow bulanannya, dimana puncak minimum inflow bulanan terjadi pada bulan September sebesar 50,2 m3/det dan mencapai puncak maksimumnya pada bulan April sebesar 222,9 m3/det. Jika dibandingkan puncak TMA dan inflownya maka ada waktu tunda (time lag) selama 2 bulan baik untuk puncak minimumnya maupun maksimumnya. Fluktuasi tinggi muka air dan inflow danau dapat dilihat pada Gambar 3.2.2

\subsection{Hubungan Curah Hujan dengan Aliran}

Hubungan antara curah hujan dengan aliran dapat diperlihatkan dengan menampilkan grafik curah hujan wilayah dengan aliran yang terjadi di outletnya. Data yang diambil adalah untuk DAS Larona seperti terlihat pada Gambar 8 yang memperlihatkan hubungan antara curah hujan wilayah dengan inflow di Towuti.

Salah satu parameter untuk melihat kondisi suatu DAS dalam menampung air adalah Koefisien aliran $\left(\mathrm{K}_{\mathrm{a}}\right) . \quad \mathrm{K}_{\mathrm{a}}$ didefinisikan sebagai perbandingan antara jumlah total aliran yang keluar dari suatu DAS / sub DAS terhadap jumlah total curah hujan yang jatuh di atasnya. Semakin kecil nilai $\mathrm{K}_{\mathrm{a}}$ maka maka semakin besar air yang tertampung / tersimpan dalam DAS tersebut yang merepresentasikan kondisi DAS tersebut masih cukup baik. Nilai $\mathrm{K}_{\mathrm{a}}$ yang besar (mendekati 1) mengindikasikan bahwa DAS tersebut sudah dalam kondisi yang kritis atau rusak. 


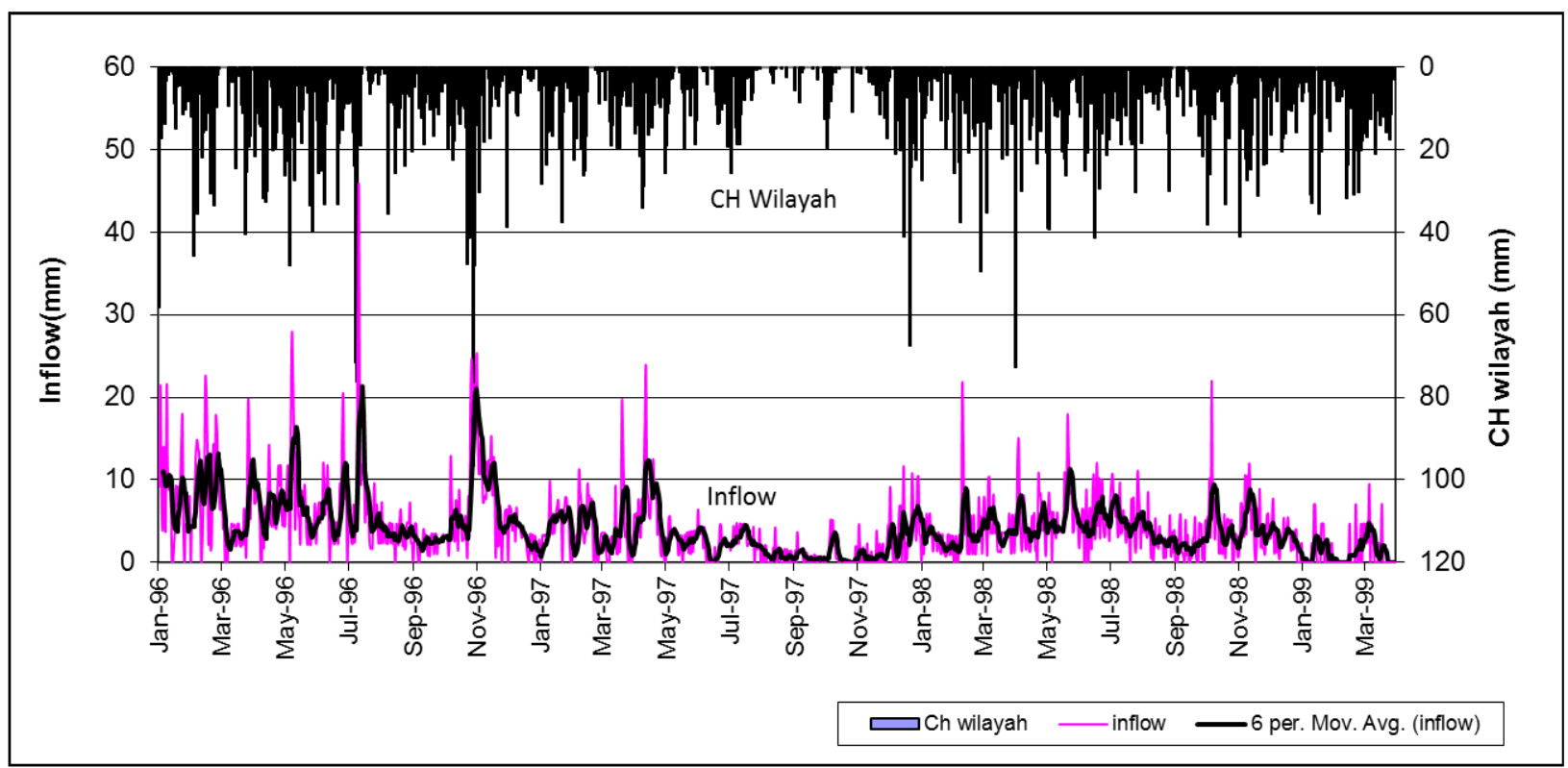

Gambar 8. Profil Inflow Towuti (terhitung) mulai Januari 1996 sampai dengan Maret 1999 dan nilai curah hujan wilayahnya (dihitung dari 7 stasiun) (diolah dari sumber : PT INCO).

Data yang dipakai untuk menghitung koefisien aliran adalah data curah hujan wilayah harian dan inflow harian. Meskipun data pengamatan curah hujan harian mencapai 9 tahun (tahun 1996 sampai 2004), tetapi data inflow harian yang didapat hanya tiga tahun (1996 sampai 1998) sehingga perhitungan koefisien aliran dihitung hanya pada durasi tersebut.

Tabel 5. Nilai Koefisien aliran $\left(K_{a}\right)$ Towuti

\begin{tabular}{||c|c|c|c|c||}
\hline \hline \multirow{2}{*}{ No } & \multirow{2}{*}{ Tahun } & $\Sigma$ Ch & $\Sigma$ Inflow & \multirow{2}{*}{ Ka } \\
\cline { 3 - 4 } & & $(\mathrm{mm})$ & $(\mathrm{mm})$ & \\
\hline \hline 1 & 1996 & 3249 & 3094 & 0.76 \\
\hline 2 & 1997 & 1035 & 1894 & 0.55 \\
\hline 3 & 1998 & 1496 & 2882 & 0.52 \\
\hline
\end{tabular}

Hasil perhitungan koefisien aliran yang tercatat selama tahun 1996 sampai 1998 disajikan dalam Tabel 5 yang diambil dari data seperti pada gambar 8. Dari nilai koefisien aliran seperti dalam Tabel 5 yang berkisar 0.6 menunjukkan bahwa DAS Larona masih berada pada kondisi moderate dalam hal sebagai reservoir (penyimpanan) air

\section{KESIMPULAN}

Dari hasil analisis memperlihatkan bahwa daerah-daerah di sekitar Mahalona, bagian tenggara Matano dan bagian Barat Laut Towuti mempunyai konsentrasi curah hujan yang paling besar. Sebaran curah hujan tahunan yang paling rendah berada di bagian selatan dari Danau Towuti.

Pola curah hujan historis DAS Larona termasuk dalam pola bimodal, masuk musim kering pada bulan Agustus dan September, sementara bulan bulan yang lain termasuk bulan basah. Curah Hujan bulanan maksimum terjadi pada bulan April dengan nilai sekitar $360 \mathrm{~mm}$, sedangkan curah hujan bulanan minimum terjadi pada bulan September sekitar $105 \mathrm{~mm}$.

DAS Larona didominasi oleh hujan ringan (kurang dari $5 \mathrm{~mm}$ dalam satu harinya) dengan durasi hujan dominan kurang dari 1 jam (rata-rata sekitar $47 \%$ dari total kejadian hujan).

\section{DAFTAR PUSTAKA}

Salby, M. L., and H. H. Hendon, 1994: Intraseasonal behavior of clouds, temperature, and motion in the Tropics. J. Atmos. Sci.,51, 2207-2224.

UPTHB, 2005. Karakteristik Hidrologi Daerah Aliran Sungai Larona Kabupaten Luwu Timur, Sulawesi Selatan, UPT Hujan Buatan, Jakarta, Tidak diterbitkan.

Harto, S. 1993. Analisis Hidrologi, PT Gramedia Pustaka Utama, Jakarta.

Tauhid, Y. I. dan Jon, A., 2000, Pengamatan Jangka Panjang Kondisi Air Danau Towuti, Jurnal Sains \& Teknologi Modifikasi Cuaca, vol.1, no. 1, Juni 2000.

Takeuchi, K. A.W. Jayawardena and Y. Takahasi (eds.) 1995 Catalogue of Rivers for Southeast Asia and the Pacific - Volume 1, The UNESCO-IHP Regional Steering Committee for Southeast Asia and the Pacific. 


\section{Lampiran 1.}
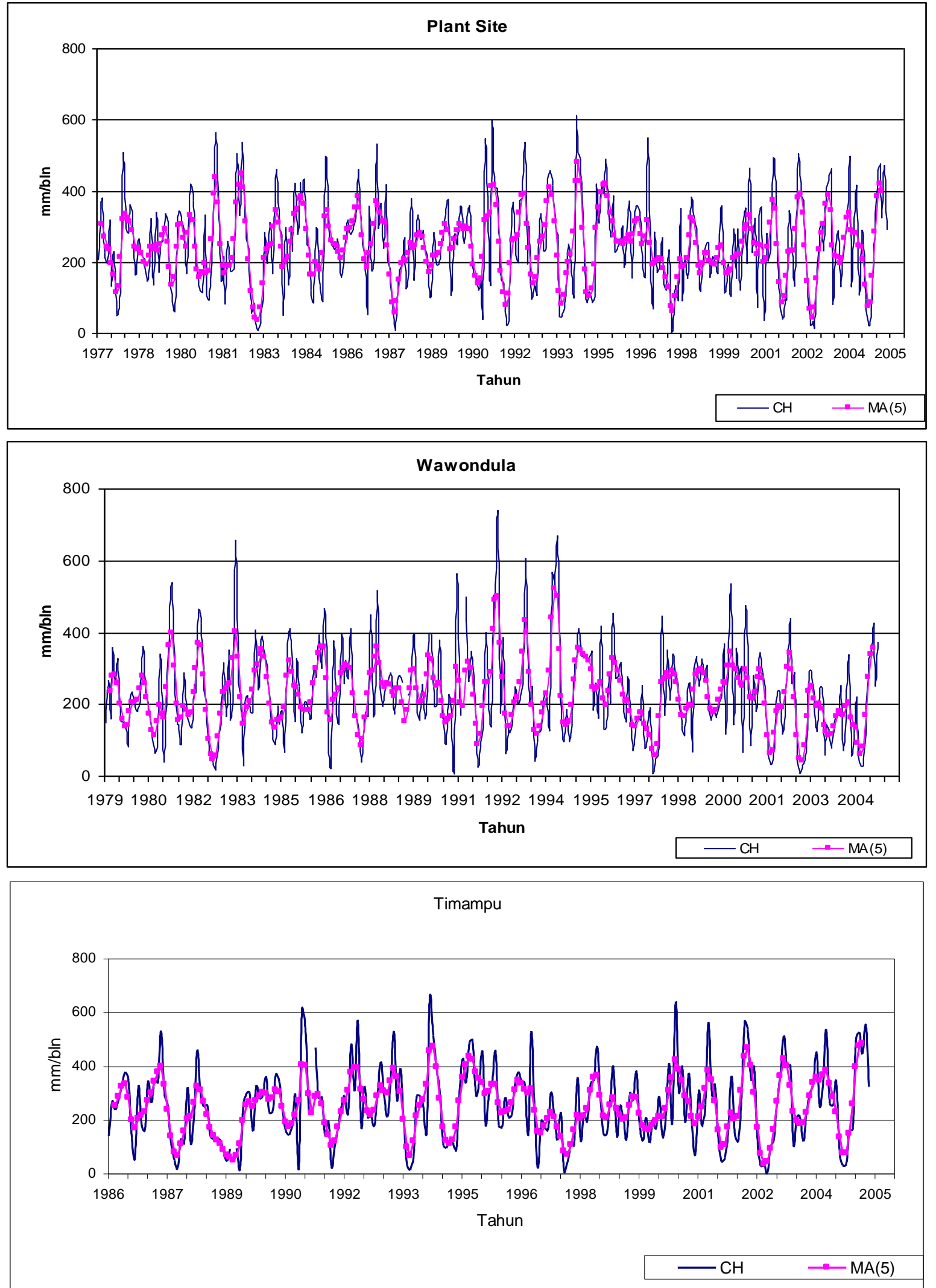

Gambar L1. Curah Hujan Bulanan time series selama 20 tahun sampai 29 tahun untuk tiga Stasiun Plant Site, Wawondula dan Timampu serta nilai Moving Average-nya(Sumber : PT INCO). 


\section{Lampiran 2.}
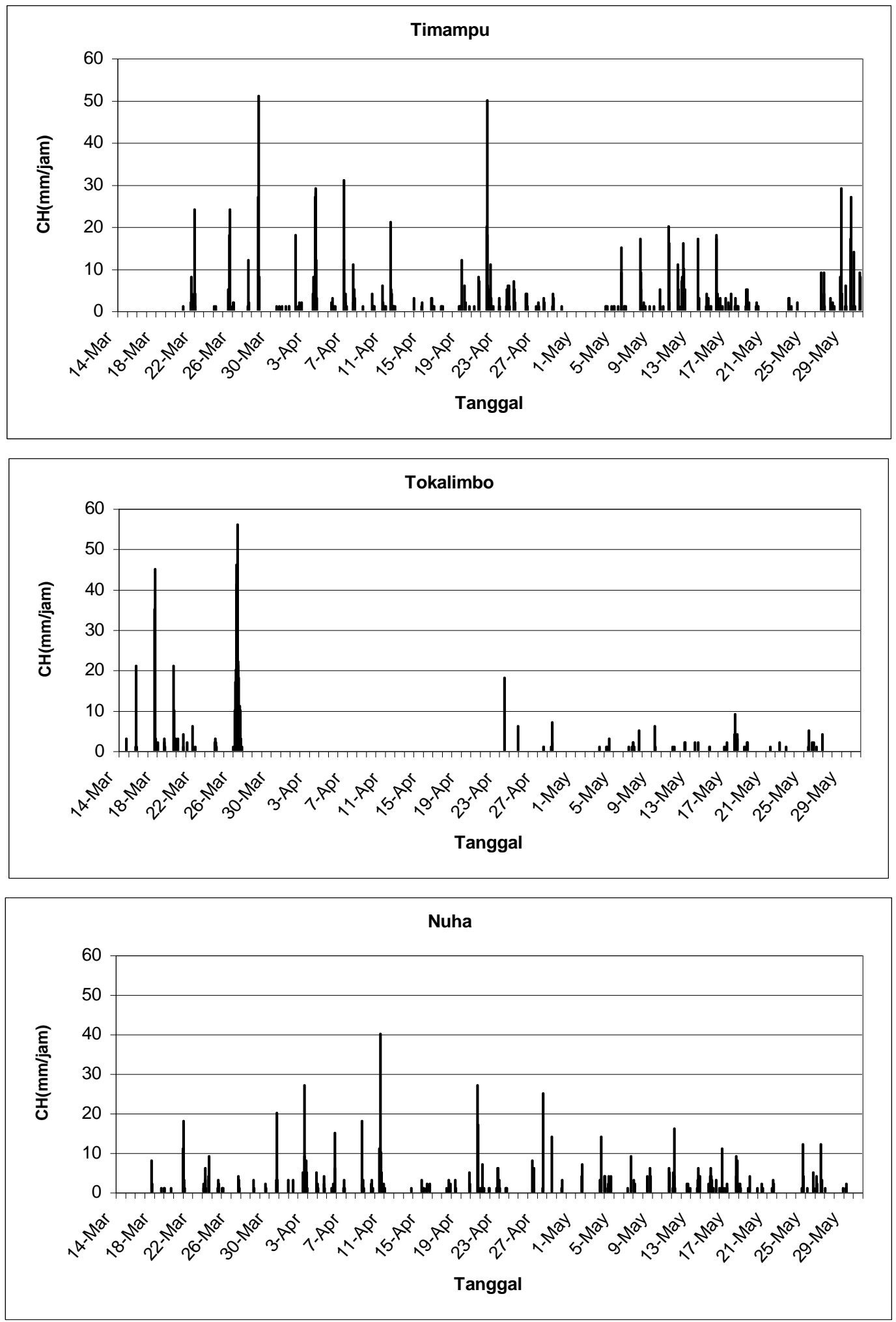

Gambar L2. Intensitas curah hujan ( $\mathrm{mm} / \mathrm{jam}$ ) dari ketiga stasiun pengamatan Timampu, Tokalimbo dan Nuha selama bulan Maret sampai May 2005 (Sumber : BPPT dan PT INCO). 
Lampiran 3.
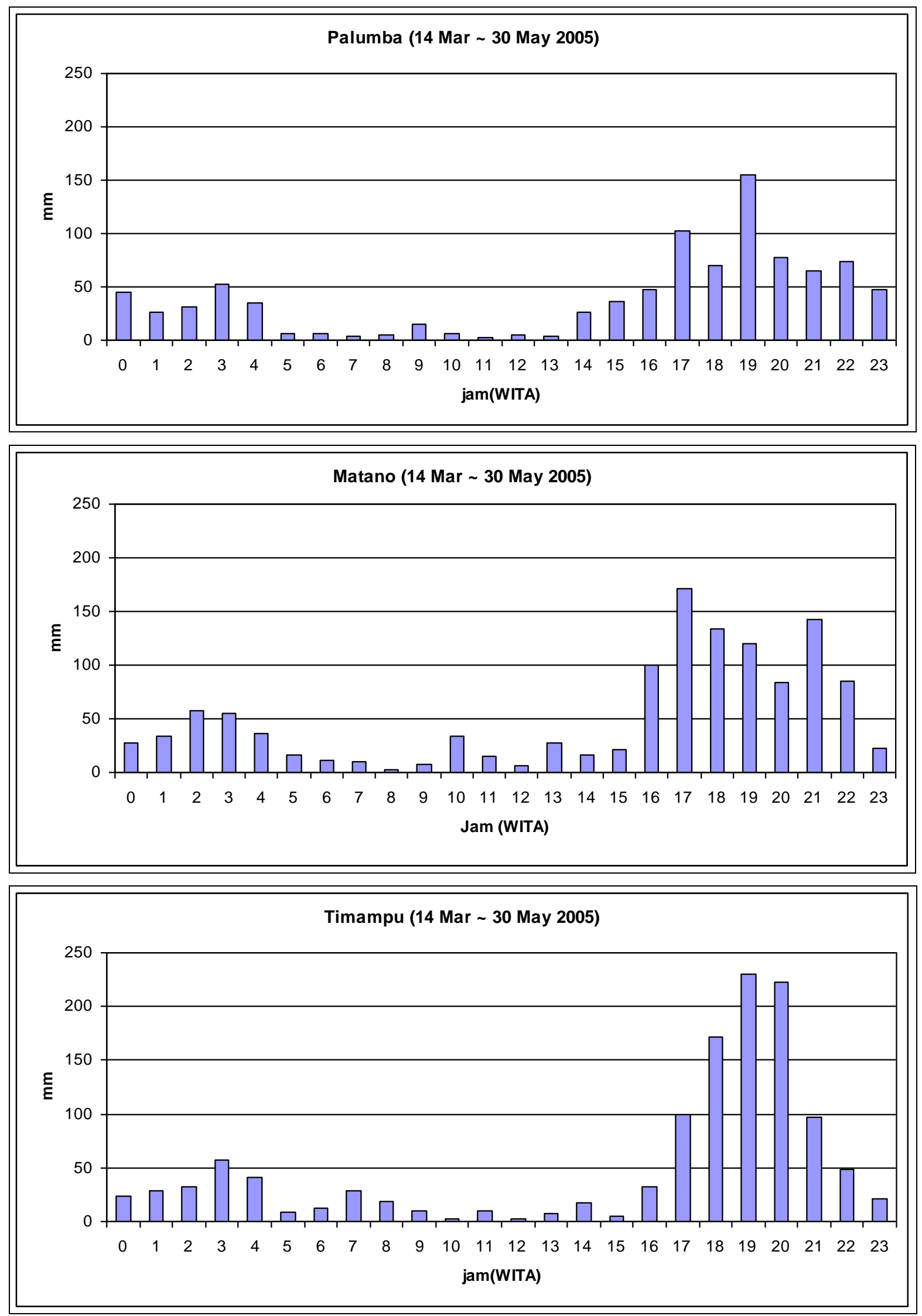

Gambar L3. Sebaran Diurnal Curah Hujan untuk tiga Stasiun Palumba, Matano dan Timampu (diolah dari sumber : PT INCO). 